\title{
Reading and Learning Difficulties in English Language Among Private and Public Primary School Pupils in the Federal Capital Territory (FCT), Nigeria
}

\author{
Dr. Odeniyi Olujinmi Adebayo \\ Image Counselling Clinic, Zamani, Abuja, Nigeria
}

Folorunsho Gbemisola Marian

National Open University of Nigeria,

Special Centre, Nigerian Public Service Institute, Kubwa, Abuja, Nigeria

doi: 10.19044/esj.2017.v13n22p163 URL:http://dx.doi.org/10.19044/esj.2017.v13n22p163

\begin{abstract}
The importance of education has often been underscored by scholars and researchers across different disciplines. Primary education is very crucial to the development of any nation. This is because of the liberating role it plays within the society. Studies have shown that when a person undergoes primary education, many problems that may constitute potential threats to the national and global well-being of a nation are solved. These problems include ignorance, illiteracy, religious violence, insecurity, and political servitude. This study investigated the reading and learning difficulties in English language among private and public primary school pupils in the Federal Capital Territory (FCT) in Nigeria. Descriptive survey research design was adopted for this study. The populations for this study are pupils of private and public primary schools in the Federal Capital Territory. It constitutes 491 primary schools in Abuja and an enrolment figure of 185,808 . The study adopts multistage sampling technique which is a probability sampling technique. Data was analysed using simple percentages, frequency counts, and tables. Findings showed that primary school pupils experience some difficulties in reading and learning English language which is the medium of instruction in their schools. Some of these problems are environment induced, while others are foundational. In conclusion, the study recommends that parents must ensure they devote adequate time to help their wards develop the interest and confidence needed to achieve comprehension. Teachers need to be more strategic in the teaching of English language, especially by encouraging listening to the language first and constant practice.
\end{abstract}


Keywords: Reading, Learning, English language, Private primary school, Public primary school, Pupils

\section{Introduction}

Ever since Nigeria attained political independence in 1960 from the British authorities, the concern of different administrations has been on how Nigeria can achieve national development. This appears to be a long wait. As at today, Nigeria is far from realising this aspiration. The education sector is one of the sectors identified as having great potentials in accelerating Nigeria's development opportunities. According to Madueke (2007), education is a life-long experience which involves physical, mental, emotional, and spiritual experiences. It also involves the development of an individual with the required skills needed to fit into the society. It is believed that the solution to all the problems confronting the nation lies in proper education of the masses (Fakeye, 2014). Education is attested to be the most powerful weapon for reducing poverty and inequality in modern societies. Also, it is useful in laying the foundation for the sustainable growth and development of any nation. "Primary education is the core of development and progress in modern societies; it is the level of education that develops in the individual the capacity to read, write, and calculate" (Domike \& Odey, 2014). Madueke (2007) further explained that there are two major types of education, namely: informal and formal education. In the Nigerian context as well as in most African countries, informal education occurs among community members with no defined curriculum, syllabus, or classroom. Its distinguishing characteristics, apart from these, is that it is one in which every member of the community are pupils and learners with no particular teacher. In addition, they do not have any formal system of grading or certification. On the other hand, formal education is a teaching-learning process based on a curriculum and which takes place in a structured environment. This type of education was brought into Nigeria by the colonial masters (Madueke, 2007). This was further fine-tuned by subsequent governments to meet the development needs of Nigeria as a country and of individual citizens.

Consequently, while so many factors may be responsible for the falling standard of education in Nigeria, one major area of concern is what needs to be done to ensure quality primary education for all Nigerian pupils. According to Mgbodile (2000), the ability to read is the key to success for most pupils. This is because reading forms the basis on which individual or group school works are done. Thus, the ability to read and write any language begins with a deep understanding of the language. English, which is Nigeria's official language, is not an exception. Griffin, Burns and Snow (2017) (nd.) points out that English language learners are at risk of future 
reading difficulties. As a result, this may result into low level of academic achievements. This is especially true for a pre-school child whose home language is not primarily English.

The ease of learning to read printed English text is likely to be impeded to some extent. This is common especially if reading instruction in English begins before the child has acquired oral proficiency in English (August \& Hakuta cited in Griffin; Burns \& Snow (n.d.) (2017)). The authors also noted other factors which may affect reading proficiency. Thus, these factors include; cultural differences between the home and school (for instance, educational values and expectations) linguistic differences, poorly educated parents, low socio-economic status (and its many concomitant conditions), living in communities in which many families are similarly struggling, and attending schools with student bodies that are predominantly minority and that have low achievement. Subsequently, learning to read and succeeding academically are two important factors affecting the educational achievements of most Nigerian pupils. This is common at the primary school level where a child gets his first formal education. Primary education is said to be the foundation upon which other forms of education are acquired later in life. However, a dysfunctional foundation definitely will affect the future and the ability of such a child to thrive academically and in all areas of the child's life. In the opinion of Asodike and Ikpitibo (2014), primary education is what "prepares the mind and trains the child for higher and tougher academic pursuits. It provides young learners with the fundamentals of reading, writing, skill acquisition, information, and the attitudes necessary for proper adjustment into the society".

Education is fundamental to the very existence of the society and it is one sure road to social, economic, cultural, and political development (Azikiwe, 2007). According to Jekayinfa and Kolawole (2008), the word "education" was derived from the Latin word "educare" meaning to bring up, to lead out, to raise up or to educate. It is defined as acting in order to lead out fully all the potentialities of an individual including helping the society in which he/she exists. Akinsola, cited in Ogunsanya and Adeyanju (1999), defined education as the aggregate of all the processes by which a child or young adult develops the abilities, attitudes and other forms of behaviour which are of positive value to the society in which he lives. Simply put, it is the development of the human being, involving different aspects of an individual such as the physical, intellectual, (mental), social, moral, spiritual, and aesthetic amongst others. To some scholars, education and schooling are not synonymous. However, in the opinion of Jekayinfa and Kolawole (2008), education consists of the formal, non-formal, and informal components. This involves the formal aspect which is sometimes referred to as schooling. Also, it is characterized by specially built institutions i.e. schools, colleges, 
universities, etc. with formalized and highly structured curricula (programmes) syllabi. In other words, schooling is an aspect of formal education. Furthermore, these authors added that "the singular purpose of education is to produce a citizen useful both to himself and the society in which he lives, and generally to the world community".

Reading, on the other hand, is defined as the process of understanding information presented in written form involving mastering the points and other supporting details (Mangvwat, 2008). Learning was defined by Gagne cited in Otubelu (2000) as a "change in human disposition or capability which persists over a period of time, and which is not ascribable to processes of growth". It also refers to a permanent change in behaviour which occurs as a result of (previous) practice, training, or experience. In other words, reading is the ability for a learner to comprehend and respond meaningfully to the content of any written document.

\section{Statement of the Problem}

It has been observed that the average Nigerian pupil is a poor and slow reader. He/she has great difficulties getting meaning out of the printed words. However, this problem was blamed on several interplaying background variables including age, socio-economic status, family attitudes, the school setting, and the environment including the teacher and his methods (Mgbodile, 2000). Educationists are of the opinion that the quality of instructors, the missing pre-school mother tongue instruction as well as the complex linguistic situations that pupils experiences in their environment are contributing to this problem. On the other hand, Shore and Sabatini (2009) noted that the issue of identifying reading difficulties and disabilities in English language learners (ELLs) is a complex one. As a result, it connects to diverse disciplines of first and second-language acquisition, literacy, and English language learning and reading. In order to provide answers to the questions raised, this study seeks to find out some of the difficulties encountered by primary school pupils in learning English language.

\section{Research Questions}

What are the difficulties pupils encounter in reading English Language?

What are difficulties pupils encounter in learning English language?

How proficient are pupils in reading and learning in English Language?

How do pupils perceive reading and learning in English language?

What is the percentage of pupils that can read English language fluently in public and private primary schools? 


\section{Methodology}

\section{Research Design}

The research design adopted in this study is the descriptive survey research design. Creswell (2014) refers to it as the procedure of inquiry which the researcher intends to adopt for the study.

\section{Population of the Study}

The populations for this study are pupils of private and public primary schools in the Federal Capital Territory in Nigeria. This constitutes 491 primary schools in Abuja with an enrolment figure of 185,808. The study adopts multistage sampling technique which is a probability sampling technique.

\section{Sample and Sampling Procedure}

The sample size was determined from the list of Private and Public schools that were randomly determined. 60 Pupils who were in primary 5 from the selected Private and Public schools participated in the study.

\section{Research Instrument}

The study adopted the questionnaire as the research instrument designed based on the research questions and objectives. The questionnaire items were titled "Reading and Learning Difficulties in English Test". This was written in simple English to ensure easy understanding by the children.

\section{Data Collection Procedure}

The research instrument was self-administered and collected immediately by the researcher who gave the children enough time to respond to the questions.

\section{Data Analysis Procedure}

Data was analysed by describing the responses as well as the use of simple percentages, frequency counts, and tables for proper understanding. 


\section{Results}

What are the difficulties pupils encounter in reading English Language?

Table 1. Showing Reading Difficulties of Respondents

\begin{tabular}{|c|c|c|c|c|}
\hline $\begin{array}{c}\text { Reading } \\
\text { difficulties }\end{array}$ & Frequency & Percentage (\%) & Public Schools & Private Schools \\
\hline Fear of mistake & 10 & 16 & 3 & 1 \\
\hline Fear of classmate & 20 & 33 & 6 & 1 \\
\hline Poor foundation & 25 & 41 & 8 & 0 \\
\hline Confident & 5 & 10 & 13 & 28 \\
\hline Total & 60 & $100 \%$ & 30 & 30 \\
\hline
\end{tabular}

In reading the passage, many of the pupils expressed fear with no sign of confidence. It appeared that they were afraid of the fact that their classmates will laugh at them or that they will fail for not getting it right. It however shows that there is a poor foundation in the basic knowledge of English language. The public pupils had a higher percentage in fear of making mistake as well as they do not want their friends to laugh at them. On the other hand, the Private school pupils showed some good level of confidence.

\section{What are the difficulties pupils' encounters in learning English Language?}

Table 2. Showing Learning Difficulties of Respondents

\begin{tabular}{|c|c|c|c|c|}
\hline Learning Difficulties & Frequency & $\begin{array}{c}\text { Percentage } \\
(\%)\end{array}$ & $\begin{array}{c}\text { Public } \\
\text { Schools }\end{array}$ & $\begin{array}{c}\text { Private } \\
\text { Schools }\end{array}$ \\
\hline $\begin{array}{c}\text { Inability to pronounce } \\
\text { words/vocabularies }\end{array}$ & 20 & 33 & 16 & 4 \\
\hline $\begin{array}{c}\text { Lack of understanding } \\
\text { new words }\end{array}$ & 15 & 25 & 14 & 1 \\
\hline $\begin{array}{c}\text { Difficulty in } \\
\text { comprehending new } \\
\text { words }\end{array}$ & 25 & 42 & 25 & 0 \\
\hline Total & 60 & $100 \%$ & & \\
\hline
\end{tabular}

Some of the respondents were unable to pronounce certain words or vocabularies such as corn, extremely, decided, neighbour, basket, dirty, pushed to mention a few. Therefore, they displayed a lack of understanding when they meet new words and when they find it hard to comprehend them e.g. extremely, neighbour. 
How proficient are pupils in reading and learning in English Language?

Table 3. Showing the Reading Ability of Respondents

\begin{tabular}{|c|c|c|c|c|}
\hline $\begin{array}{c}\text { Reading } \\
\text { ability }\end{array}$ & Frequency & $\begin{array}{c}\text { Percentage } \\
(\%)\end{array}$ & Public Schools & Private Schools \\
\hline Read fluently & 31 & $52 \%$ & 13 & 24 \\
\hline Not fluent & 18 & $30 \%$ & 9 & 6 \\
\hline Cannot read & 11 & $18 \%$ & 8 & 0 \\
\hline Total & 60 & $100 \%$ & 30 & 30 \\
\hline
\end{tabular}

Out of the 60 pupils sampled, 57 attempted to read and 3 were not willing to try. Again, out of the 60, only 31 could read fluently, 18 were not fluent, and 11 could not read at all.

\section{How do pupils perceive reading and learning in English language?}

Table 4. Showing the Passion Pupils Exhibit towards Reading and Learning

\begin{tabular}{|c|c|c|c|c|}
\hline Passion to Read & Frequency & $\begin{array}{c}\text { Percentage } \\
(\%)\end{array}$ & $\begin{array}{c}\text { Public Schools } \\
\%\end{array}$ & $\begin{array}{c}\text { Private Schools } \\
\%\end{array}$ \\
\hline $\begin{array}{c}\text { Passionate } \\
\text { about learning }\end{array}$ & 48 & $80 \%$ & 75 & 95 \\
\hline $\begin{array}{c}\text { Not passionate } \\
\text { about learning }\end{array}$ & 12 & $20 \%$ & 25 & 5 \\
\hline Total & 60 & $100 \%$ & & \\
\hline
\end{tabular}

Table 4 shows respondents passion for learning. While $80 \%$ are passionate about learning and did not even want the discussion to end as they were interested in the vocabularies in the comprehension, 20\% showed no concern and were not passionate about learning. However, they were satisfied watching the other pupils participate in the exercise.

Table 5. Showing Pupils' Perception of Reading and Learning in English Language

\begin{tabular}{|c|c|c|c|c|}
\hline Perception of pupils & Frequency & Percentage (\%) & Public Schools & $\begin{array}{c}\text { Private } \\
\text { Schools }\end{array}$ \\
\hline Good perception & 29 & $48 \%$ & 12 & 17 \\
\hline Not concerned & 12 & $20 \%$ & 10 & 2 \\
\hline Difficult & 19 & $32 \%$ & 19 & 0 \\
\hline Total & 60 & $100 \%$ & & \\
\hline
\end{tabular}

Among the respondents, 29 (48\%) have good perception about reading and learning in all the sampled classes, while 12 (20\%) perceives it as just a way of life or a necessity as it is taught in school. The remaining 19 (32\%) perceived reading and learning as too difficult and not friendly. They explained that they cannot assimilate. Above all, they acted in a way that shows they are not in. 
What is the percentage of pupils who can read fluently in public and private schools?

Table 6. Showing the Percentage of Respondents who can Read Fluently in Public Schools

\begin{tabular}{|c|c|c|}
\hline Ability to read & Frequency & Percentage (\%) \\
\hline Read fluently & 13 & $43 \%$ \\
\hline Not fluent & 9 & $30 \%$ \\
\hline Difficult & 8 & $27 \%$ \\
\hline Total & 30 & $100 \%$ \\
\hline
\end{tabular}

The above table shows that $13(43 \%)$ pupils in public schools can read fluently, $9(30 \%)$ are not fluent in reading, and $8(27 \%)$ cannot read.

Table 7. Showing the Percentage of Respondents who can Read Fluently in Private Schools

\begin{tabular}{|c|c|c|}
\hline Ability to read & Frequency & Percentage (\%) \\
\hline Read fluently & 24 & $80 \%$ \\
\hline Not fluent & 6 & $20 \%$ \\
\hline Difficult & 0 & $0 \%$ \\
\hline Total & 30 & $100 \%$ \\
\hline
\end{tabular}

Table 7 shows that in private schools, $24(80 \%)$ can read fluently while only $6(20 \%)$ are not fluent in reading.

\section{Discussion of Data}

Basically, the ability to read is the key to success for most pupils according to Mgbodile (2000). This is because reading forms the basis on which individual or group school works are done. Our findings show that most of the pupils sampled expressed fear and no confidence in reading. This signals a potential problem which may hamper the success of many of these pupils. This also underscores the importance of the learning environment which in this study poses a threat in the sense that the pupils were afraid of their peers. Therefore, this could be surmounted with discipline which Azikiwe (2007) describes as a good and cordial relationship between the teacher and pupils. Also, it can be developed through interesting activities.

According to Mgbodile (2000), the ability to read and write any language begins with a deep understanding of the language. The responses of the respondents shows that there is no deep understanding of the language as most of them displayed weak mastery of some words and vocabularies. Algeo (2010) acknowledges the fact that English language has an extraordinarily large vocabulary including words we have little occasion to use or recognize. However, the fact that this is the official language in Nigeria makes it an important language for everyone. Azikiwe (2007) avers that the best way a Nigerian child could learn English Language is by listening and speaking it. He opines that this can easily be achieved if the 
child is assisted to learn these four basic skills; listening, speaking, reading, and writing.

Subsequently, the data gathered shows that majority are fluent in reading, while many of them demonstrated a strong passion for reading and learning English language. This is a positive indication of the pupil's willingness to learn. While a significant number of the respondents had a positive perception of reading and learning English language, the percentage of respondents who indicated a poor perception and interest in the language is worrisome. Thus, this reflects a potential problem based on the overall performance of such pupils in every other subject which adopts English language as a medium of instruction. The result revealed that pupils in private schools can read more fluently than those in public schools. This result is not surprising when considered in light of the various submissions of scholars on the depreciating significance appropriated to education.

Apart from the fact that teachers are generally poorly motivated, most public schools suffer from lack of attention from government. Equipment is usually inadequate. Also, teachers and learning resources are inadequate. Private schools are better because parents who enrol their wards in such schools are willing to pay more leaving those who cannot to a dysfunctional foundation.

\section{Recommendations}

A child can possess the right confidence to reading and learning through the support of the parents. Therefore, parents are encouraged to help their children develop reading skills by encouraging them to read at home from an early age. This is attributed to the fact that research has shown that children start to demonstrate eagerness to learn before the age of five. Parents therefore must ensure they devote adequate time into helping their wards develop the interest and confidence needed to achieve comprehension.

Teachers, on the other hand, have the responsibility of helping their pupils become active learners by engaging them in various activities that will make learning interesting to them. The school/class environment must be conducive for learning. Education in Nigeria has suffered many setbacks as a result of the direct neglect of the sector by the governments of different administration. The state of most public institutions leaves doubt in the minds of many regarding the quality of the products of such institutions. In view of this, education will only receive a bounce back when government pays the right attention to the sector. This can be achieved when the government invest in the training of human resources, as well as improve the infrastructural deficiencies of the educational sector. 


\section{References:}

1. Algeo, J. (2010). The Origins and Development of the English Language ( $6^{\text {th }}$ edition). Wadsworth: Cengage Learning.

2. Asodike, J.D. and Ikpitibo, C.L. (2014). Basic issues in primary education delivery in Nigeria. European Scientific Journal. January edition, Vol. 8, No1, pp.662-666. http://eujournal.org/index.php/esj/article/viewFile/4608/4404.

3. Azikiwe, U. (2007). Language Teaching and Learning. Onitsha: Africana First Publishers Limited.

4. Creswell, J.W. (2014). Research Design: Qualitative, quantitative and mixed method approaches. (4 ${ }^{\text {th }}$ ed.) Thousand Oaks: Sage Publications Inc.

5. Domike, G.C. and Odey, E.O. (2014). An Evaluation of the Major Implementation Problems of Primary School Curriculum in Cross River State, Nigeria. American Journal of Educational Research, 20142 (6), pp 397-401. DOI: 10.12691/education-2-6-12.

6. Fakeye, D.O. (2014). The Role of Teachers in Nation Building. Global Teacher Magazine.Vol. 1, October edition. Ibadan: Image J. Communications, pp. 9-10.

7. Jekayinfa, A.A. and Kolawole, D.O. (2008). Conceptual Background to the History of Education in Nigeria. Perspectives on the History of Education in Nigeria cited on http://www.unilorin.edu.ng/publications/jekayinoluwa/CONCEPTUA LBACKGROUND.doc.

8. Mangvwat, S.E. (2008). A Guide to Effective Study Skills. Pankshin: Eureka Academic Foundation.

9. Ogunsanya and Adeyanju ed. (1999). Fundamental Principles of Education. Ibadan: Andrian Publication Series.

10. Otubelu, O.D. (2000). Human Learning: A Psychological Viewpoint. Ashantek Publishers Ltd.

11. Shore, J.R. and Sabatini, J. (2009). English Language Learners with Reading Disabilities: A Review of the Literature and the Foundation for a Research Agenda. ETS, Princeton: NJ retrieved from www.ets.org/research.html on May 1, 2017.

12. Snow, Burns and Griffin (n.d) (2017). English Language Learners and Reading Difficulties. Reading Rockets. Retrieved from www.readingrockets.org on May 1. 